\title{
Characterization of aquifer parameter in basaltic hard rock region through pumping test methods: a case study of Man River basin in Akola and Buldhana Districts Maharashtra India
}

\author{
S. F. R. Khadri ${ }^{1} \cdot$ Kanak Moharir $^{1}$
}

Received: 4 November 2015/Accepted: 7 November 2015/Published online: 19 February 2016

(C) Springer International Publishing Switzerland 2016

\begin{abstract}
Aquifer parameters transmissivity ' $\mathrm{T}$ ' and storage coefficient ' $\mathrm{S}$ ' are very important parameters to assess the groundwater potential either through mathematical modeling or any conventional methods. In early days, these parameters are estimated either by means of in situ test or performing test on aquifer samples brought in the laboratory. In recent times, the pumping test has become an important method to estimate these parameters. This is the only method that provides simultaneous information on the hydraulic behavior of the well (borehole), the reservoir and the reservoir boundaries, which are essential for efficient aquifer and well field management. The applicability of the result from the laboratory test has limitations while in situ tests give representative aquifer parameters. The most common in situ test is pumping test performed on wells, which involves the measurement of the fall and rise of water level with respect to time. Theis (American Geophysics Union Transcripts, 16th annual meeting, part 2, pp 519-524, 1935) was first to propose method to evaluate aquifer parameters from the pumping test on a bore well in a confined aquifer. Since then, several methods have been developed to analyze the pumping test data (time-drawdown) under different conditions. For the characterization of the aquifer parameters in Man River basin area, it is essential to know the Transmissivity ( $\mathrm{T}=\mathrm{Kb}$ where, $\mathrm{b}$ is the aquifer thickness: pumping flow rate, $\mathrm{Q}=\mathrm{TW}(\mathrm{dh} / \mathrm{dl})$ flow through an aquifer) and Storativity (confined aquifer, $\mathrm{S}=\mathrm{bSs}$, unconfined, $\mathrm{S}=\mathrm{Sy}$ ) so as to predict the rate of drawdown of the water table/
\end{abstract}

S. F. R. Khadri

khadrisfr@rediffmail.com

1 Department of Geology, Sant Gadge Baba Amravati University, Amravati, MS 446002, India potentiometric surface during the pumping of an aquifer. The determination of aquifer's parameters is an important basis for groundwater resources evaluation, numerical simulation, development and protection as well as scientific management. Pumping test is a main method for determining aquifer's parameters. A study area shows that this method has rapid speed and high accuracy. The results of parameter's determination are optimized so that it has important practical value for scientific research and engineering practice.

Keywords Pumping test method - Aquifer - Pumping well · Theis's type curve method - Aquifer test 2014 software

\section{Introduction}

The water demand for industrial, agricultural, and domestic uses is continuously increasing and freshwater resources are shrinking. Against this backdrop, groundwater management is a critical issue for current and future generations. Groundwater management entails both quantity and quality-related groundwater resource management. Hard rock aquifer occupies the first few tens of meters from the top (Detay et al. 1989; Taylor and Howard 2000) that is subjected to weathering process (Wyns et al. 2002). Groundwater occurs in weathered and fractured layers under unconfined to semi confined conditions, which have specific hydrodynamic properties from the top to the bottom. Quantification of groundwater resources and understanding of hydrogeologic processes is a basic prerequisite for efficient and sustainable management of groundwater resource development and management (Sophocleous 1991; Vander Gun and Lipponen 2010). This is particularly 
vital for India where $80 \%$ of Indian peninsula is covered with hard rocks coupled with widely prevalent semi-arid climate (Pathak 1984).

About two-thirds of the Indian Territory comprising the central, western and southern peninsula is covered by different types of hard rocks such as basalts, granites, gneisses, etc. Western and central India is occupied by tholeiitic basaltic lava flows of the Deccan traps sequence. The Deccan traps occupy a vast terrain between $69^{\circ}-79^{\circ} \mathrm{E}$ long. and $16^{\circ}-22^{\circ} \mathrm{N}$ lat. constituting one of the largest volcanic provinces on the earth. The Deccan traps sequence consists of multiple layers of solidified lava flows. The basaltic flows vary in color from dark grey to purple and pink. Each lava flow consists of an upper vesicular unit and a lower massive unit which may or may not be fractured/jointed. Two lava flows at some places are separated by inter-trappean alluvium area. Therefore, unlike other hard rocks, the Deccan traps behave as a multi-aquifer system, somewhat similar to a sedimentary rock sequence. Acute shortage of groundwater in hard-rock areas, such as the Deccan traps, is well known. Groundwater available in shallow, weathered mantle under unconfined condition above the Deccan traps is inadequate to meet the ever-increasing demand of water supply. Maharashtra too is occupied by hard rock's whose receptiveness of precipitation is restricted to the degree of weathering and secondary porosity, so also its capacity to store and transmit the water. As a result, even in high rainfall areas of the state, water scarcity is experienced in summer months. Hard rock's derive its status as an aquifer on the basis of secondary porosity that gets developed due to decompose and weathering processes over a period of time (Radhakrishna 1970). The aquifers in hard-rock are unconfined and their water table generally follows the surface topography. Therefore, there is a good match between the surface drainage (watershed) and groundwater system (aquifer geometry). Thus, it becomes imperative to understand the hard rock physiographic, its characteristics vis-à-vis availability of groundwater. The shallow aquifers are phreatic and found to be occurring up to the depth of 10-15 m underlain by massive rocks which forms the bottom of phreatic aquifer.

The groundwater in shallow aquifers gets replenished annually as the monsoon rainfall occurs only within a 4-month period (June to September). The pre and post monsoon water levels indicate the degree of saturation in the hard rock aquifer network of 20 observation wells has been calculated in Man River basin area and water levels are recorded since last 2 years. An analysis of water level data has indicated that declining of water level trends could occur even in the underdeveloped watersheds indicating that there are various factors influencing in declining of water level, time and Discharge data. During the drawdown phase of a pumping test on a large diameter well, most of the pumped water initially comes from well, most of the pumped water initially comes from well storage. It is only after some time that the aquifer starts contributing to the pump age. The time gap between the onset of pumping and the beginning of an appreciable flow of water from the aquifer to the well depends mostly on the transmissivity of the aquifer. Other factors being the same the lower the aquifer transmissivity, the longer the pumping time required to produce pumping test data with a discernible signature which can be interpreted to determine the aquifer parameters (Fig. 1). Sometimes, in low permeability formations, this condition may not be attained during the drawdown period. One must, therefore, continue observations during the recovery phase (Singh and Gupta 1986). A cut off point for recovery observations in the well needs to be established. Due to a slow rate of recovery in a low permeability aquifer, one may be tempted to stop the observations too soon to capture the information contained in the later segment of the time recovery curve. This paper presents details of a few pumping test and data analysis which lead to a reasonable criterion for the extent of recovery that should be observed.

\section{Study area}

The present study is based on the hydrogeological data obtained for large-diameter dug wells tapping unconfined aquifers in various parts of Maharashtra and considers the potential of the above five groups as aquifers. The area under study is forming a part of the Akola and Buldhana District, Maharashtra, India, located close to the western margin of the Deccan traps terrain about $25 \mathrm{~km} \mathrm{SW}$ of Chikali Taluka. $20^{\circ} 54^{\prime} 59^{\prime \prime} \mathrm{N}$ latitude and $76^{\circ} 41^{\prime} 23^{\prime \prime} \mathrm{E}$ longitude. The study area is covered by Survey of India toposheets 55D/7, 55D/9, 55D/11, 55D/13, 55D/14 and $55 \mathrm{D} / 15$ on $1: 50,000$ scale. The east to west monsoon (during middle June to September) contributes more than $70 \%$ of the rainfall. Rainwater is the main source for recharging of groundwater. The location map of the study area is shown in Fig. 2.

\section{Geology of area}

Physiographically, the study area can be broadly divided into low lying plain towards the banks of the Man River in the northeast and horizontal Deccan Trap flows with multiple scarps and abrupt cliffs towards the southern parts. The study area consists of various erosional surfaces in step-like terraces. The horizontal dispositions of the lava flows with a fair degree of uniformity in lithology have considerably simplified the changes brought by the secondary processes like weathering and denudation. Differential weathering forces has resulted in wiping out of thick lava pile (Fig. 3). 
Fig. 1 Illustration of a semiconfined aquifer condition pumping test

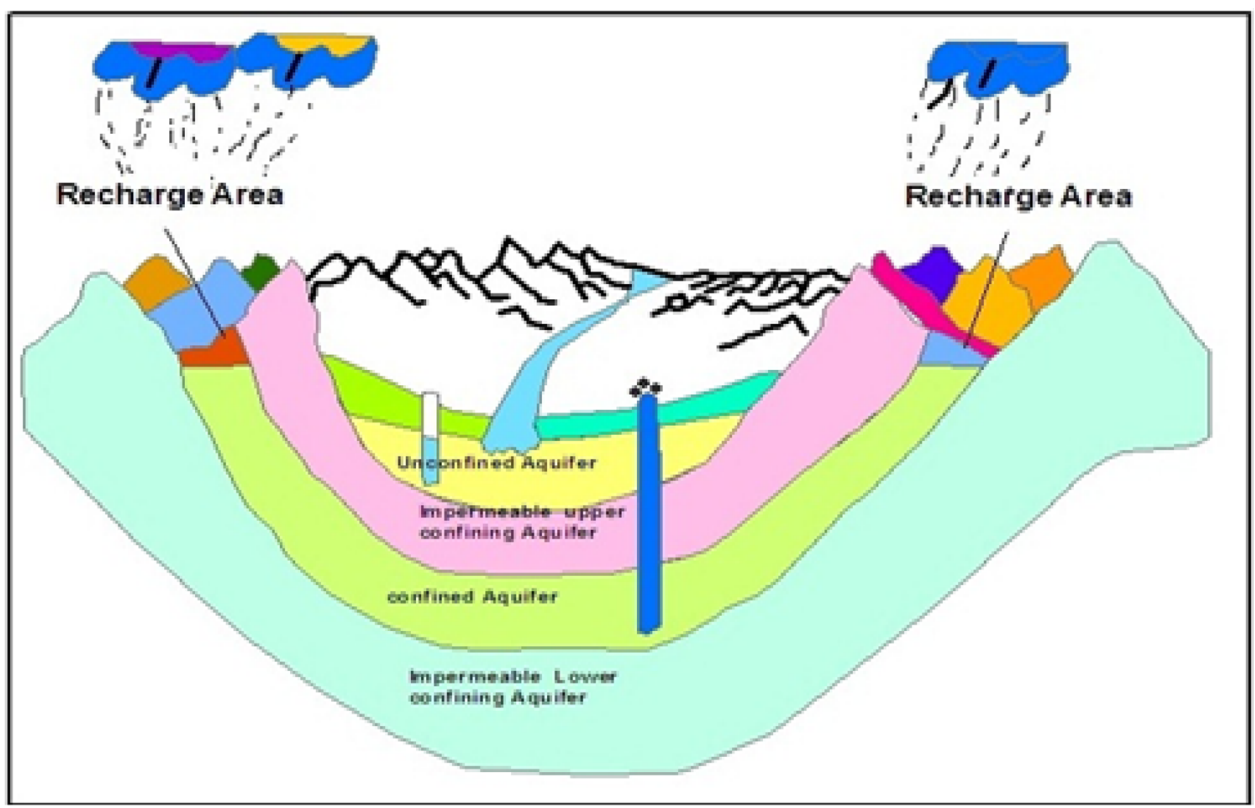

\section{Rainfall}

The area receives major part of the rainfall (about $45 \%$ ) during South-West-monsoon period there are eleven rain gauge stations in the area which have rainfall recorded for more than 50 years. The normal rainfall for Akola and Buldhana districts is $800-1200 \mathrm{~mm}$ (source IMD). It is minimum in the North-Western part of the district and increases towards the South Eastern parts of the district i.e. toward Washim district. The percentage of probability of receiving normal rainfall over the district has been studied.

\section{Agriculture}

Agriculture plays an important role in the economic development of Akola and Buldhana districts of Maharashtra. Nearly $80 \%$ of the total area is arable and most of the total population is engaged in different agricultural activities. The farmers' are harvesting two crops in a year. Ground water the most important natural source that is widely used in agricultural production amounts to nearly $80 \%$ of the total irrigated area.

\section{Methodology}

\section{Proposed research}

In reality, more than one of the above factors could be responsible. To resolve the question as to whether current groundwater abstraction is sustainable requires an understanding of the groundwater system including a detailed knowledge of the aquifer parameters. It should then be possible to predict how water levels in, and around, an irrigation well or group of irrigation wells, respond to pumping and whether the aquifer resources are sufficient to sustain that level of groundwater development. Further, and perhaps of greatest importance, it should indicate the likelihood of excessive abstraction by wells lowering water levels in public supply wells and in the worst case causing the latter wells to be abandoned. Once the sustainable resource is known then further investigations into the effects of reduced recharge due to climate change, water management strategies and agricultural practices can be carried out.

\section{Pumping tests and methods}

A pumping test is the best available method to evaluate aquifer parameters. This test Involves extracting water from a well at a controlled rate and observing the water level Changes in the pumped well and/or in one or more observation wells, with respect to time (Theis 1935; Singhal and Gupta 1999). During the past few decades, researchers have proposed several different methods to analyze the pumping test data and estimate the aquifer Parameters (Theis 1935; Cooper and Jacob 1946; Hantush and Jacob 1955; Hantush 1960, 1966; Javandel and Witherspoon 1983; Theim 1906; Raj 2001). Among the main techniques are; analytical/conventional methods and numerical methods. Analytical/conventional methods involve one of the following: (1) curve matching, (2) finding inflection points, or for special cases, (3) fitting straight lines to the pumping test data. In curve matching 

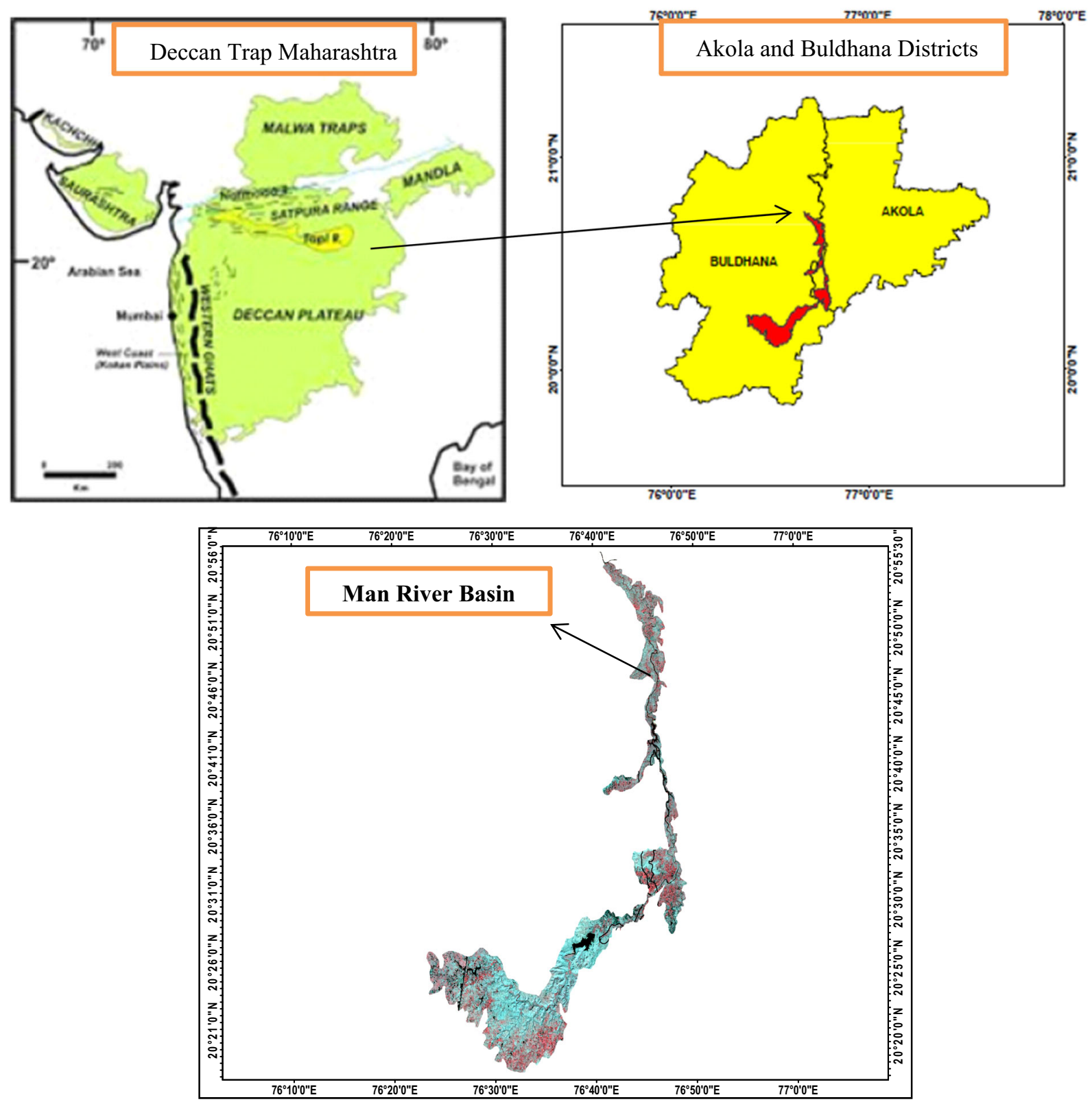

Fig. 2 Location map of study area

techniques, field results are generally plotted and matched against the results of analytical solutions. There are also several alternative techniques for estimating aquifer parameters from the pumping phase (like log-log plots and log-arithmetic plots), as well as techniques for estimating aquifer parameters from the recovery phase. Comparatively, the numerical method uses a single model to obtain a "best fit" between the field and modeled results for both the pumping and recovery phases (using different parameters). A trial and error technique is employed to obtain a best fit (Ruston 2003). The entire computation procedure and hydrological equations is typically written into a computer program(s). Each of the methods described above are based on basic assumptions relating to the basic type of well such as well diameter, dug well, and bore well. Therefore, it is important to choose the right method of interpretation based on the field conditions (Kruseman and de Ridder 1970).

\section{Current study, methods and results}

In the study presented here, pumping tests were conducted on large diameter wells in basaltic terrain within the Chikali region of Maharashtra. An attempt was made to 
Fig. 3 Geology map of Man River basin

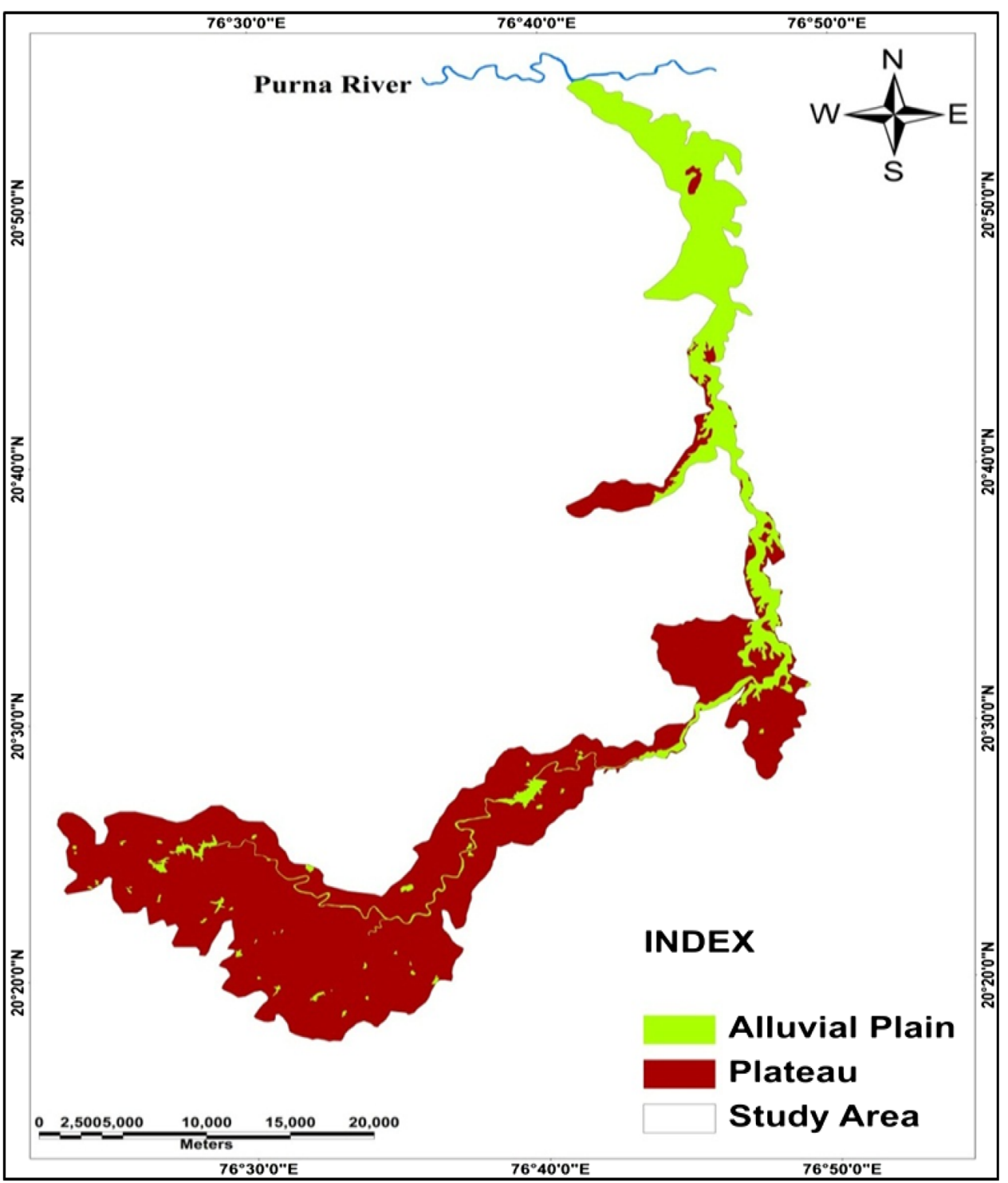

interpret the pumping data by using two conventional methods: the Papadopoulos and Cooper method (1967) and one numerical method, as proposed by Singh and Gupta (1991). In this study, Aquifer test 2014 version software is being used including pumping test method which has proved to be a quick and easy way to interpret the data through the software program. It is specifically designed for graphical analysis and reporting of pumping test data. There are two types of methods in this software such as to create pumping test and slug test. In this present study, use of creating pumping test method through the software is being applied.

\section{Details of pumping tests}

A pumping test is the best available method to evaluate aquifer parameters. This test involves extracting water from a well at a controlled rate and observing the water level changes in the pumped well and/or in one or more observation wells, with respect to time (Theis 1935; Singhal and Gupta 1999). During the past few decades, researchers have proposed several different methods to analyze the pumping test data and estimate the aquifer parameters (Theis 1935; Cooper and Jacob 1946; Hantush and Jacob 1955; Hantush 1960, 1966; Javandel and Witherspoon 1983; Theim 1906; Raj 2001). Pumping tests either inject or remove fluid from a borehole and measure the response (change in pressure) of the aquifer in the same or in nearby observation boreholes. A model is used to estimate aquifer properties (usually hydraulic conductivity and specific storage) from the hydraulic response. The values of the aquifer properties that are obtained will depend on the model that is used to interpret the test results. Most models for interpreting pumping tests 
represent the aquifer as a homogeneous, isotropic porous medium, and adopt one of three basic geometries. Spherical flow models describe fluid flow toward a spherical cavity in a homogeneous porous medium of infinite extent in all directions (Fig. 4). Flow is three-dimensional, and equipotential surfaces are concentric spheres around the spherical cavity. Flow is two-dimensional, and equipotential surfaces are cylinders centered about the well axis. This geometry might also represent a horizontal fracture zone or a single horizontal fracture bounded by impermeable rock. Linear flow geometry describes flow that is unidirectional, such as linear flow towards a highly transmissive vertical fracture that intersects a well. Combinations of these three basic geometries are also possible (Table 1).

There are a number of reasons why pumping tests are unlikely to provide useful continuum estimates of aquifer hydraulic conductivity in fractured rocks. Firstly, the estimate of hydraulic conductivity is highly sensitive to the model chosen to analyses the data. Often none of the simplistic models represented by Fig. 3 are appropriate, yet this may not be obvious from test results. Observed hydraulic head data may still superficially resemble one of these models.

\section{Interpretation of pumping test data}

The pumping test is generally used to study the parameters like storativity, transmissivity and yield characters of the well (Table 2). These values define the aquifer characteristics. In Deccan traps, the large diameter dug wells, Papadopoulos and Cooper (1967) method is the right procedure to arrive at aquifer parameters (Karanth 1987; Kruseman and de Ridder 1970). In the present study

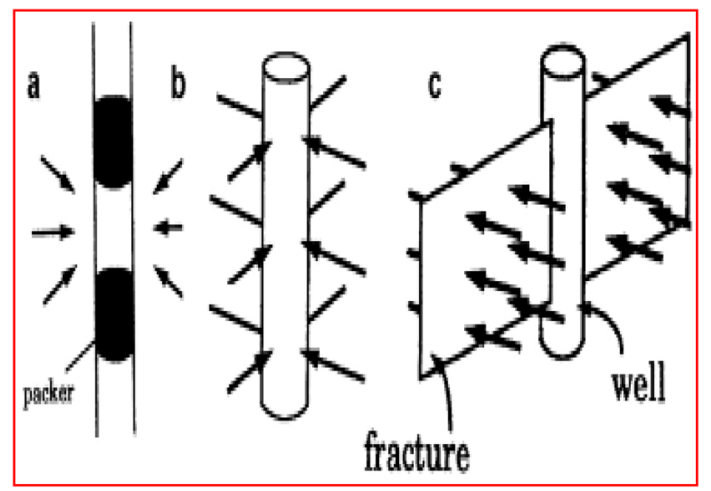

Fig. 4 Contrasting models of groundwater flow to a well that are used for interpreting single well hydraulic tests. a Flow to a short test interval in a bore hole that approximates spherical geometry (interval length! Bore hole radius); b Radial flow to a cylinder; and $\mathbf{c}$ linear flow to a well that intersects a highly transmissive vertical fracture. (Source: NRC 1996)
Papadopoulos and Cooper (1967) method is adopted to determine the aquifer parameters and also to analyze pumping test data.

In this method, plots of time draw down data on double logarithmic paper are prepared for all the pumped wells. These plots are matched with the Papadopoulos and Cooper (1967) type curves. This study has demonstrated the occurrence of mini basins showing specific groundwater flows in the area of investigation which is separated from each other by a permeability barriers or a high. Recharge experiment have also indicated the beneficial areas of irregular shape and eccentric outline with respect to recharge location. This study has given rise to the areal extent and depth of penetration, which in turn helpful in determining the volume. The storativity (S), transmissivity (T) and specific yield values have been computed. The location of pumping test from which the overall groundwater potential of the basins, present draft, net balance of water available and the stage of development of the basin have been determined. A numerical method (Singh and Gupta 1986), coupled with an optimization technique was considered appropriate for data interpretation as it fully takes into account the well storage effect. The method is valid for a confined aquifer which was true in case studied. The first step of this method consists of the computation of drawdown (s) and the residual drawdown $\left(\mathrm{s}^{\prime}\right)$ in the well after each time interval of 5 min for computing and $\mathrm{s}^{\prime}$, the following relationships as given by Papadopoulos and cooper (1967) are used. Here $\Delta \beta=[\beta$ J0 $(\beta)-2 \alpha \mathrm{J} 1(\beta)$ $2+[\beta Y 0(\beta)-\alpha 2$ Y1 ( $\beta)$ 2]. Ji and Yi are Bessel functions of it order of the first and second kind, respectively. Values of $\mathrm{s}$ and $\mathrm{s}^{\prime}$ may be computed by assuming some initial values of $\mathrm{T}$ and $\mathrm{S}$ the computed values of $\mathrm{s}$ and $\mathrm{s}^{\prime}$ are then compared with the observed ones the computed and observed values of $\mathrm{s}$ and $\mathrm{s}^{\prime}$ is the most significant step in the estimation of aquifer parameters.

\section{Results, discussion and recommendations}

The transmissivity values for well number $15,12,7$ and 6 are found to be $22.91,58.12,22.81$ and 24.68 sq.mt/day respectively. The standard value of transmissivity for Deccan trap is 30-100 sq.mt/day. The calculated value of transmissivity $(\mathrm{T})$ are according to the standards the specific capacity values calculated for well numbers 5,12,7 and 6 are $22.2233 .72,22.49$ and $61.47 \mathrm{lit} / \mathrm{min} / \mathrm{m}$ respectively. The storage coefficient values for well no. 15, 12, 7, 6 are $0.118,0.220,0.0290$ and 0.20 respectively, which are relatively comparable to the standard values for Deccan trap aquifers due to compact and massive trap is at lower elevation in the study area. The values of safe yield (QS) for same wells are 35,500, 67.445, 22.939 and 
Table 1 Details of the pumping test data

\begin{tabular}{|c|c|c|c|c|c|c|}
\hline $\begin{array}{l}\text { Well } \\
\text { no. }\end{array}$ & Location of well & $\begin{array}{l}\text { Duration of pumping } \\
\text { (min) }\end{array}$ & $\begin{array}{l}\text { Maximum draw drown } \\
\text { (m) }\end{array}$ & $\begin{array}{l}\text { Duration of recovery } \\
\text { (min) }\end{array}$ & $\begin{array}{l}\text { Residual draw } \\
\text { down }\end{array}$ & $\begin{array}{l}\text { Aquifer } \\
\text { type }\end{array}$ \\
\hline 1 & Padsul & 140 & 18.82 & 190 & 0.42 & WVB \\
\hline 2 & Chatari & 170 & 11.92 & 150 & 0.03 & $\mathrm{JMB}$ \\
\hline 3 & Sirla & 170 & 9.25 & 180 & 0.17 & VB \\
\hline 4 & Wadali & 170 & 10.05 & 90 & 0.78 & JMB \\
\hline 5 & Tarkhed & 120 & 8.04 & 35 & 1.82 & FMB \\
\hline 6 & PimpariDhanagar & 150 & 10.21 & 110 & 1.52 & WSMB \\
\hline 7 & Satargaon & 130 & 16.68 & 80 & 0.81 & JMB \\
\hline 8 & Hiwarakhurd & 120 & 6.35 & 115 & 0.08 & FMB \\
\hline 9 & Manegaon & 160 & 21.00 & 80 & 4.50 & FMB \\
\hline 10 & Batwadibudruk & 200 & 14.10 & 150 & 0.10 & WVB \\
\hline 11 & Ghuighui & 170 & 19.40 & 200 & 0.07 & WMB \\
\hline 12 & Amdapur & 210 & 8.70 & 205 & 0.40 & WMB \\
\hline 13 & Dastapur & 105 & 13.70 & 90 & 0.05 & FMB \\
\hline 14 & Mohadari & 280 & 9.00 & 250 & 1.60 & FMB \\
\hline 15 & Pardi & 230 & 2.80 & 210 & 0.30 & JMB \\
\hline 16 & pimparkhed & 110 & 15.9 & 100 & 1.62 & WSMB \\
\hline 17 & Songiri & 250 & 10.5 & 120 & 1.72 & WSMB \\
\hline 18 & Tandi & 200 & 11.4 & 170 & 0.15 & VB \\
\hline 19 & Uti & 140 & 20.6 & 220 & 0.92 & JMB \\
\hline 20 & Wadali & 160 & 18.23 & 90 & 1.92 & FMB \\
\hline
\end{tabular}

$S$ saturated, $B$ basalt, $F$ fractured, $J$ jointed, $M$ massive, $V$ vesicular, $W$ weathered

60.247 lts./day respectively. The result of 20 pumping test carried out in the study area follows that there are presence of three categories of wells having excellent, moderate and low productivity of wells. Well number 2, $3,4,5,8,9,10,11,13,14$ and 1 show excellent potential for the groundwater exploration with higher safe yields. Whereas well numbers 6 and 12 showing moderate productively with medium safe yield well no. 7 and 15 show low potential with very low safe yield and poor recuperation and hence are not suitable for further development. The recommendation includes further development of well no. 2,10 and 14 which can increase groundwater potential with upward rise with safe yields. Whereas well no. 1, 3, 5, 8, 9, 10,11 and 13 does not require further development, as these have already reached optimum level of production (Table 3).

The results of pumping test data shows that in each basin, the transmissivity and permeability values are very similar to one another indicating free movement of groundwater within the basin limits with the presence of permeability barrier towards the 'high' where the values reduce drastically. These values will also be helpful in further determining the boundaries of the basin which differs from the other basin in these respects. Considering the free movement of groundwater within the limits of basin, well location can be more accurately identified based on the shapes of the contours. The result of the pumping test data shows that there are limited groundwater prospects in the region which certainly needs careful planning and management of the available water resource (Tables 4 , $5,6,7)$. The Time and Drawn Graph of villages are shown in Fig. 5a-c).

\section{Theis's type curve method}

Theis's type curve method is presented type curve which is the plotted values of $\mathrm{W}(\mathrm{u})$ and $1 / \mathrm{u}$ on $\log -\log$ sheet. The field values of drawdown and time are plotted on similar $\log -\log$ sheet. The field curve is matched with the type curve keeping the axes of the curves parallel (Fig. 6). In the matched position a match point is selected. The values of $\mathrm{W}(\mathrm{u})$ and $1 / \mathrm{u}$ for this match point is read from the type curve. Similarly the values of $s$ and $t$ are read from the field curve. Substituting these values of $\mathrm{W}(\mathrm{u}), 1 / \mathrm{u}, \mathrm{s}$ and $\mathrm{t}$ in Eq. (9) and (10) gives the values of $\mathrm{T}$ and $\mathrm{S}$.

There are four types of Theis's curve method;

1. Log-Log Method,

2. Semilog Method

3. Recovery method. Template 
Table 2 Details of well design data for the study area

\begin{tabular}{|c|c|c|c|c|c|}
\hline Well no. & Well location & Type of aquifer & Diameter of the well & Depth of the well & Static water level \\
\hline 1 & Padsul & WVB & 4.10 & 20.00 & 15.10 \\
\hline 2 & Chatari & SMB & 2.70 & 12.00 & 8.25 \\
\hline 3 & Sirla & VB & 3.15 & 10.30 & 7.30 \\
\hline 4 & Wadali & JMB & 5.10 & 10.10 & 7.10 \\
\hline 5 & Tarkhed & FMB & 4.60 & 8.50 & 5.08 \\
\hline 6 & PimpariDhanagar & WJMB & 3.50 & 10.30 & 7.30 \\
\hline 7 & Satargaon & JMB & 2.90 & 17.00 & 13.45 \\
\hline 8 & Hiwarakhurd & FMB & 3.50 & 6.60 & 4.42 \\
\hline 9 & Manegaon & WVB & 4.35 & 20.90 & 14.20 \\
\hline 10 & Batwadibudruk & WMB & 3.60 & 15.00 & 12.10 \\
\hline 11 & Ghuighui & WMB & 4.00 & 20.00 & 16.32 \\
\hline 12 & Amdapur & WMB & 2.80 & 8.80 & 4.40 \\
\hline 13 & Dastapur & FMB & 3.00 & 14.20 & 10.35 \\
\hline 14 & Mohadari & FMB & 2.45 & 9.00 & 6.30 \\
\hline 15 & Pardi & JMB & 2.30 & 9.20 & 6.40 \\
\hline 16 & Pimparkhed & VB & 3.22 & 11.2 & 7.4 \\
\hline 17 & Sirla & FMB & 3.32 & 8.90 & 10.20 \\
\hline 18 & Tarkhed & JMB & 4.70 & 16.30 & 12.30 \\
\hline 19 & Uti & FMB & 2.60 & 14.50 & 11.40 \\
\hline 20 & Wadali & WVB & 4.80 & 20.20 & 5.60 \\
\hline
\end{tabular}

$S$ saturated, $B$ basalt, $F$ fractured, $J$ jointed, $M$ massive, $V$ vesicular, $W$ weathered

Table 3 Hydraulic parameters calculated from aquifer test

\begin{tabular}{|c|c|c|c|c|}
\hline Well no. & Safe yield QS (Lts/day) & Specific capacity $(\mathrm{min} / \mathrm{mt}$ of $\mathrm{D} / \mathrm{D})$ & Transmissivity $\mathrm{T}\left(\mathrm{m}^{2} /\right.$ day $)$ & Storage coefficient $S$ \\
\hline 1 & $1,36,125$ & 92.08 & 35.11 & 0.036 \\
\hline 2 & 9,382 & 38.12 & 37.42 & 0.044 \\
\hline 3 & $1,06,503$ & 50.18 & 74.43 & 0.101 \\
\hline 4 & $1,23,694$ & 113.80 & 34.92 & 0.021 \\
\hline 5 & $1,14,557$ & 75.00 & 43.73 & 0.022 \\
\hline 6 & 50,257 & 62.47 & 24.58 & 0.030 \\
\hline 7 & 23,849 & 23.49 & 22.87 & 0.0380 \\
\hline 8 & $1,86,027$ & 108.70 & 64.77 & 0.130 \\
\hline 9 & $1,62,812$ & 83.52 & 86.18 & 0.020 \\
\hline 10 & $1,55,718$ & 64.35 & 44.20 & 0.080 \\
\hline 11 & $3,10,520$ & 75.20 & 27.13 & 0.015 \\
\hline 12 & 67,475 & 30.72 & 52.12 & 0.330 \\
\hline 13 & $1,74,430$ & 85.66 & 34.53 & 0.070 \\
\hline 14 & $1,32,760$ & 70.93 & 50.00 & 0.016 \\
\hline 15 & 38,540 & 21.35 & 22.80 & 0.117 \\
\hline 16 & 50,252 & 68.48 & 23.50 & 0.040 \\
\hline 17 & 23,879 & 23.60 & 22.90 & 0.0400 \\
\hline 18 & $1,85,022$ & 108.90 & 64.74 & 0.125 \\
\hline 19 & $1,62,716$ & 82.56 & 86.15 & 0.030 \\
\hline 20 & $1,55,728$ & 64.46 & 45.20 & 0.060 \\
\hline
\end{tabular}


Table 4 Details pumping test data of Man River basin

\begin{tabular}{|c|c|c|c|c|c|c|c|c|c|}
\hline \multirow{2}{*}{$\begin{array}{l}\text { Time } \\
(\min )\end{array}$} & \multirow{2}{*}{$\begin{array}{l}\text { Water level } \\
\text { (fit) }\end{array}$} & \multicolumn{2}{|c|}{ Ambeshwar village } & \multicolumn{2}{|c|}{ Amdapur village } & \multicolumn{2}{|c|}{ Change phal village } & \multicolumn{2}{|c|}{ Dhanori village } \\
\hline & & $\begin{array}{l}\text { Time } \\
(\min )\end{array}$ & $\begin{array}{l}\text { Water level } \\
\text { (fit) }\end{array}$ & $\begin{array}{l}\text { Time } \\
(\min )\end{array}$ & $\begin{array}{l}\text { Water level } \\
\text { (fit) }\end{array}$ & $\begin{array}{l}\text { Time } \\
(\min )\end{array}$ & $\begin{array}{l}\text { Water level } \\
\text { (fit) }\end{array}$ & $\begin{array}{l}\text { Time } \\
(\min )\end{array}$ & $\begin{array}{l}\text { Water level } \\
\text { (fit) }\end{array}$ \\
\hline 1 & 4.12 & 1 & 4.2 & 1 & 7 & 1 & 5.6 & 1 & 9.1 \\
\hline 3 & 5.11 & 3 & 6.3 & 3 & 8.7 & 2 & 7.2 & 2 & 9.4 \\
\hline 4 & 6.8 & 4 & 7.8 & 5 & 8.6 & 4 & 8.4 & 3 & 12.4 \\
\hline 5 & 7.2 & 5 & 8.9 & 10 & 7.1 & 5 & 6.12 & 5 & 10.3 \\
\hline 8 & 8.4 & 10 & 10.11 & 20 & 5.2 & 8 & 7.6 & 8 & 9.75 \\
\hline 10 & 9.6 & 20 & 12.4 & 50 & 8.62 & 10 & 8.14 & 10 & 4.9 \\
\hline 25 & 10.1 & 50 & 9.6 & 100 & 12.15 & 18 & 9.2 & 20 & 9.6 \\
\hline 30 & 11.2 & 80 & 8.12 & 200 & 6.4 & 20 & 10.11 & 30 & 9.12 \\
\hline 50 & 12.6 & 100 & 10.6 & 500 & 6.1 & 30 & 9.6 & 50 & 10.1 \\
\hline 80 & 10.5 & 200 & 11.8 & 800 & 8.6 & 50 & 10.5 & 100 & 9.85 \\
\hline 100 & 11.3 & 500 & 12.6 & 1000 & 15 & 80 & 11.2 & 200 & 12.3 \\
\hline 200 & 12.9 & 800 & 13.2 & 1500 & 9.5 & 100 & 8.6 & 400 & 10.87 \\
\hline 500 & 13.2 & 1000 & 12.8 & 2000 & 5.8 & 500 & 12.8 & 500 & 9.93 \\
\hline 1000 & 10.8 & 1550 & 13.4 & 2500 & 15 & 800 & 11.14 & 1000 & 8.63 \\
\hline 1500 & 13.4 & 2000 & 12.12 & 3000 & 9.1 & 1000 & 13.2 & 2000 & 5.9 \\
\hline
\end{tabular}

Table 5 Details pumping test data of Man River basin

\begin{tabular}{|c|c|c|c|c|c|c|c|c|c|}
\hline \multicolumn{2}{|c|}{ Mohadari village } & \multicolumn{2}{|c|}{ Mundephal village } & \multicolumn{2}{|c|}{ Pardi village } & \multicolumn{2}{|c|}{ PimpalKhuta Village } & \multicolumn{2}{|c|}{ Pimparidhangar } \\
\hline $\begin{array}{l}\text { Time } \\
(\min )\end{array}$ & $\begin{array}{l}\text { Water level } \\
\text { (fit) }\end{array}$ & $\begin{array}{l}\text { Time } \\
(\min )\end{array}$ & $\begin{array}{l}\text { Water level } \\
\text { (fit) }\end{array}$ & $\begin{array}{l}\text { Time } \\
(\min )\end{array}$ & $\begin{array}{l}\text { Water level } \\
\text { (fit) }\end{array}$ & $\begin{array}{l}\text { Time } \\
(\min )\end{array}$ & $\begin{array}{l}\text { Water level } \\
\text { (fit) }\end{array}$ & $\begin{array}{l}\text { Time } \\
(\min )\end{array}$ & $\begin{array}{l}\text { Water level } \\
\text { (fit) }\end{array}$ \\
\hline 1 & 6.7 & 1 & 5.2 & 1 & 5.8 & 1 & 5.5 & 1 & 5.2 \\
\hline 2 & 8.9 & 2 & 4.38 & 2 & 6.1 & 2 & 6.8 & 2 & 6.4 \\
\hline 3 & 10.12 & 3 & 6.4 & 5 & 12 & 3 & 7.9 & 3 & 7.6 \\
\hline 4 & 9.5 & 4 & 5.6 & 10 & 11.5 & 5 & 8.12 & 5 & 8.8 \\
\hline 5 & 10.32 & 5 & 7.8 & 20 & 12.8 & 10 & 10.15 & 8 & 9.2 \\
\hline 10 & 9.8 & 10 & 8.8 & 30 & 15.5 & 20 & 10.5 & 10 & 10.11 \\
\hline 20 & 11.5 & 20 & 9.2 & 50 & 7.2 & 30 & 9.6 & 15 & 8.4 \\
\hline 30 & 10.62 & 30 & 8.12 & 100 & 8.18 & 40 & 11.4 & 20 & 11.6 \\
\hline 50 & 11.55 & 40 & 10.11 & 200 & 9.8 & 100 & 9.12 & 30 & 11.7 \\
\hline 100 & 12.3 & 50 & 9.4 & 500 & 11.7 & 150 & 11.6 & 40 & 10.5 \\
\hline 200 & 10.4 & 80 & 10.18 & 800 & 10.9 & 200 & 10.18 & 50 & 9.6 \\
\hline 500 & 12.8 & 100 & 11.5 & 1000 & 11.5 & 500 & 12.6 & 100 & 12.2 \\
\hline 800 & 13.5 & 200 & 12.2 & 1500 & 11.38 & 900 & 11.8 & 200 & 11.8 \\
\hline 1000 & 11.6 & 500 & 11.8 & 2000 & 11.88 & 1000 & 12.4 & 500 & 12.5 \\
\hline 2000 & 13.8 & 1000 & 12.8 & 2500 & 12.2 & 2000 & 13.6 & 1000 & 13.4 \\
\hline
\end{tabular}

4. Time Drawn Method (Log Log Method) (Figs. 6, 7, 8, 9).

Cooper and Jacob (1946) modified the Theis method and suggested an easy method to determine aquifer parameters. The method does not require curve matching. The time- drawdown data is plotted on semi-log paper (time on log axis and drawdown on linear axis). The additional condition required to use this method is that the test should be conducted for enough time so that the value of $u$ should be 
Table 6 Details pumping test data of Man River basin

\begin{tabular}{|c|c|c|c|c|c|c|c|c|c|}
\hline \multicolumn{2}{|c|}{ DhatraNaik village } & \multicolumn{2}{|c|}{ Ghuti village } & \multicolumn{2}{|c|}{ HiwaraKhurd village } & \multicolumn{2}{|c|}{ Isoli village } & \multicolumn{2}{|c|}{ Karkhed village } \\
\hline $\begin{array}{l}\text { Time } \\
(\min )\end{array}$ & $\begin{array}{l}\text { Water level } \\
\text { (fit) }\end{array}$ & $\begin{array}{l}\text { Time } \\
(\min )\end{array}$ & $\begin{array}{l}\text { Water level } \\
\text { (fit) }\end{array}$ & $\begin{array}{l}\text { Time } \\
(\min )\end{array}$ & $\begin{array}{l}\text { Water level } \\
\text { (fit) }\end{array}$ & $\begin{array}{l}\text { Time } \\
(\mathrm{min})\end{array}$ & $\begin{array}{l}\text { Water level } \\
\text { (fit) }\end{array}$ & $\begin{array}{l}\text { Time } \\
(\min )\end{array}$ & $\begin{array}{l}\text { Water level } \\
\text { (fit) }\end{array}$ \\
\hline 1 & 6.1 & 1 & 5.2 & 1 & 4.12 & 1 & 3.8 & 1 & 4.3 \\
\hline 4 & 8.5 & 2 & 6.12 & 3 & 6.8 & 2 & 4.2 & 2 & 6.2 \\
\hline 5 & 7.6 & 5 & 8.35 & 5 & 8.9 & 3 & 5.11 & 5 & 8.4 \\
\hline 6 & 8.8 & 10 & 10.4 & 10 & 10.12 & 4 & 6.8 & 10 & 9.5 \\
\hline 7 & 6.4 & 15 & 11.6 & 25 & 10.42 & 5 & 7.4 & 20 & 8.6 \\
\hline 8 & 10.2 & 20 & 11.45 & 35 & 11.9 & 10 & 8.11 & 30 & 9.3 \\
\hline 10 & 9.3 & 50 & 12.5 & 55 & 10.6 & 20 & 9.12 & 40 & 8.6 \\
\hline 20 & 10.5 & 80 & 10.7 & 80 & 11.14 & 30 & 10.5 & 50 & 10.2 \\
\hline 30 & 9.5 & 100 & 7.8 & 100 & 12.2 & 40 & 11.14 & 80 & 9.7 \\
\hline 40 & 11.1 & 150 & 9.9 & 200 & 11.8 & 50 & 10.8 & 100 & 10.11 \\
\hline 100 & 10.8 & 200 & 10.25 & 500 & 12.5 & 100 & 11.15 & 150 & 12.6 \\
\hline 200 & 11.5 & 500 & 12.9 & 650 & 13.4 & 200 & 9.15 & 250 & 11.12 \\
\hline 500 & 12.6 & 800 & 13.8 & 800 & 12.8 & 500 & 12.8 & 300 & 12.8 \\
\hline 1000 & 10.4 & 1000 & 13.73 & 1000 & 13.2 & 800 & 13.2 & 500 & 11.6 \\
\hline 1540 & 12.12 & 1500 & 12.11 & 1440 & 9.91 & 1000 & 13.9 & 1000 & 13.2 \\
\hline
\end{tabular}

Table 7 Details pumping test data of Man River basin

\begin{tabular}{|c|c|c|c|c|c|c|c|c|c|}
\hline \multicolumn{2}{|c|}{ Pimparkhed village } & \multicolumn{2}{|c|}{ Sirla village } & \multicolumn{2}{|c|}{ Tarkhed village } & \multicolumn{2}{|c|}{ Uti village } & \multicolumn{2}{|c|}{ Wadali village } \\
\hline $\begin{array}{l}\text { Time } \\
(\min )\end{array}$ & $\begin{array}{l}\text { Water level } \\
\text { (fit) }\end{array}$ & $\begin{array}{l}\text { Time } \\
(\min )\end{array}$ & $\begin{array}{l}\text { Water level } \\
\text { (fit) }\end{array}$ & $\begin{array}{l}\text { Time } \\
(\min )\end{array}$ & $\begin{array}{l}\text { Water level } \\
\text { (fit) }\end{array}$ & $\begin{array}{l}\text { Time } \\
(\min )\end{array}$ & $\begin{array}{l}\text { Water level } \\
\text { (fit) }\end{array}$ & $\begin{array}{l}\text { Time } \\
(\min )\end{array}$ & $\begin{array}{l}\text { Water level } \\
\text { (fit) }\end{array}$ \\
\hline 1 & 5.6 & 3 & 4.8 & 1 & 6.9 & 1 & 4.9 & 1 & 6.9 \\
\hline 3 & 6.8 & 5 & 5.2 & 2 & 12 & 2 & 5.32 & 3 & 7.8 \\
\hline 5 & 7.11 & 8 & 6.4 & 3 & 16 & 3 & 8.2 & 5 & 10.5 \\
\hline 8 & 6.12 & 10 & 7.2 & 4 & 15.15 & 5 & 11.5 & 10 & 12.1 \\
\hline 10 & 8.14 & 20 & 8.6 & 5 & 6.6 & 10 & 10.4 & 20 & 13.6 \\
\hline 20 & 7.22 & 30 & 9.1 & 10 & 8.18 & 20 & 11.7 & 40 & 14.3 \\
\hline 30 & 9.13 & 40 & 10.12 & 20 & 13.63 & 50 & 12.2 & 60 & 14.48 \\
\hline 50 & 10.11 & 50 & 11.7 & 30 & 7.2 & 80 & 9.46 & 100 & 15.4 \\
\hline 80 & 8.5 & 100 & 10.6 & 40 & 10.5 & 100 & 7.8 & 300 & 13.1 \\
\hline 90 & 10.4 & 400 & 11.12 & 80 & 10.2 & 200 & 12.9 & 500 & 13.63 \\
\hline 100 & 11.2 & 500 & 12.2 & 100 & 8.71 & 500 & 13.5 & 800 & 12.8 \\
\hline 250 & 12.5 & 800 & 10.6 & 200 & 6.17 & 800 & 15.6 & 1000 & 12.2 \\
\hline 300 & 11.8 & 1000 & 13.2 & 300 & 7.3 & 1000 & 8.4 & 1440 & 13.55 \\
\hline 500 & 12.9 & 1440 & 12.4 & 500 & 8.9 & 2000 & 10.7 & 1500 & 10.4 \\
\hline 1000 & 13.4 & 2000 & 13.8 & 1000 & 7.6 & 3000 & 12.5 & 1550 & 10.75 \\
\hline
\end{tabular}

less than 0.01 (Figs. 10, 11). A straight line is drawn through the data points and the slope $(\Delta s)$ of the straight line is determined. The time $\left(t_{0}\right)$ is also noted where the straight line intercepts the time axis (i.e. at $s=0$ ).
The following formulas are used to calculate the aquifer parameters.

$T=2.3 \frac{Q}{(4 \pi \Delta s)}, \quad S=2.25 \frac{T t_{0}}{r . r}$ 


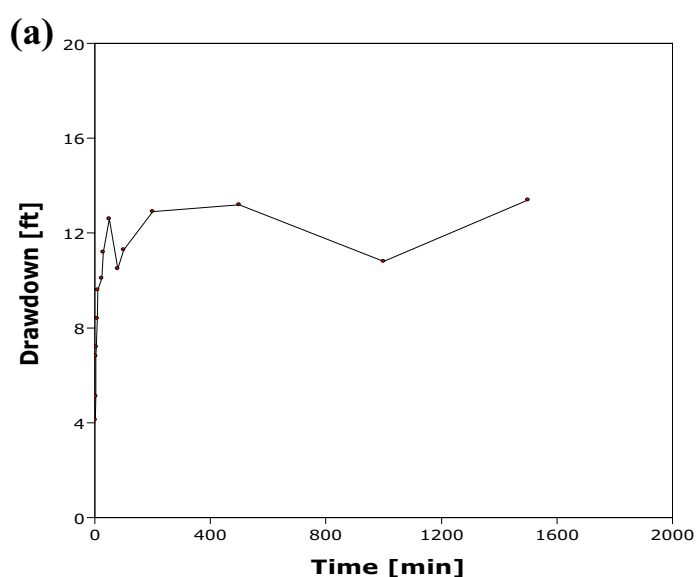

(i) Ainkhed

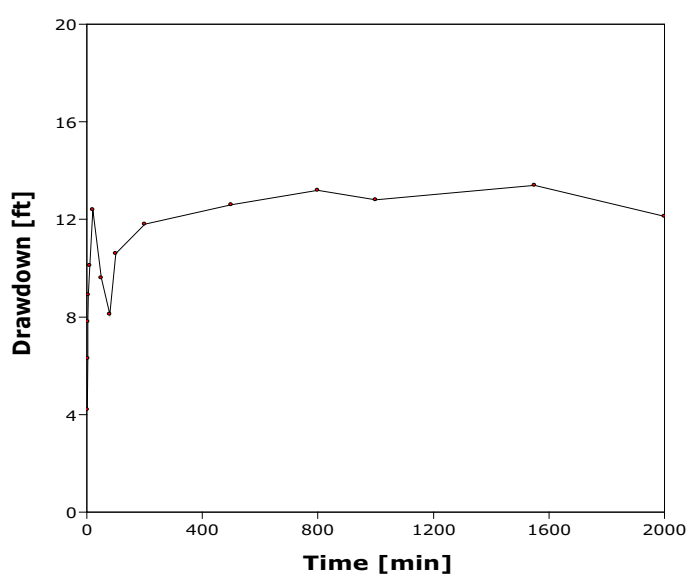

(ii) Ambeshwar

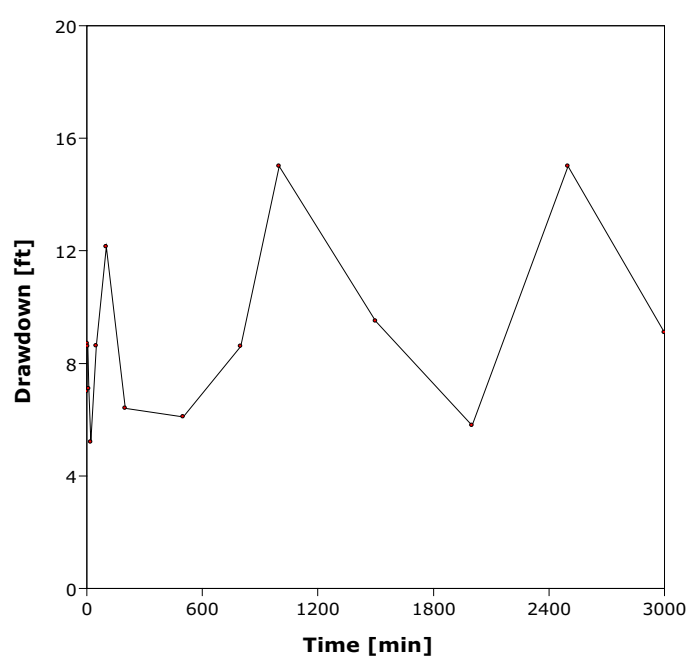

(iii) Amdapur

Fig. 5 a Time and Drawn Graph of (i) Ainkhed, (ii) Ambeshwar, (iii) Amdapur, (iv) phal, (v) Dhanori, (vi) Dhatra Naik, (vii) Ghuti, (Viii) Hiwara Khurd pumping test by using aquifer software 2014. b Time and Drawn Graph of (ix) Isoli, (x) Karkhed, (xi) Mohadari, (xii)

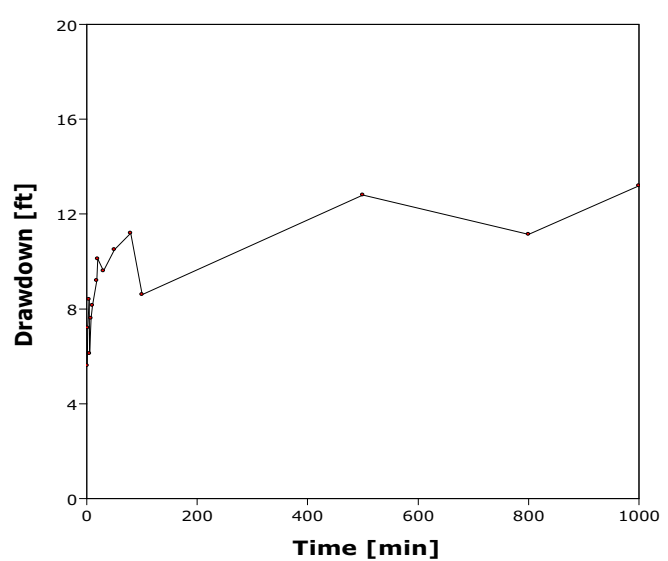

(iv) phal

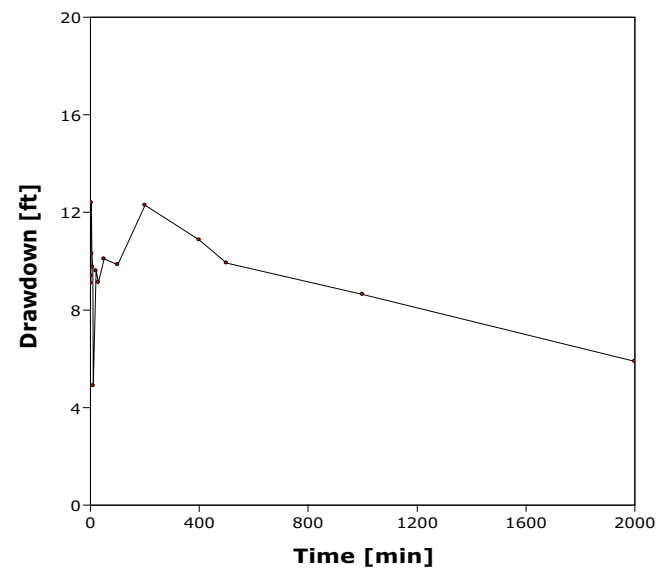

(v) Dhanori

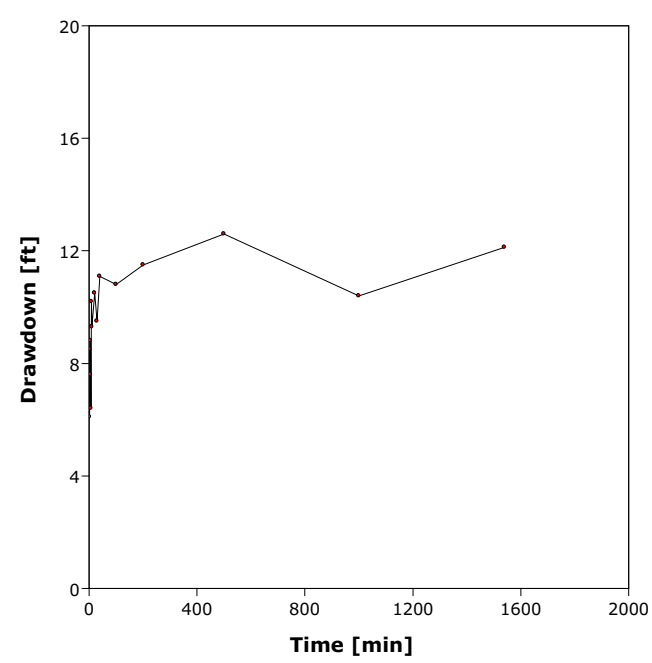

(vi) Dhatra Naik

Mundephal, (xiii) Pardi, (xiv) Pimpal Khuta, (xv) Pimpari Dhangar, (xvi) Pimpar khed pumping test by using aquifer software 2014. c Time and Drawn Graph (xvii) Sirla, (xvii) Tarkhed, (xix) Uti, (xx) Wadali of pumping test by using aquifer software 2014 


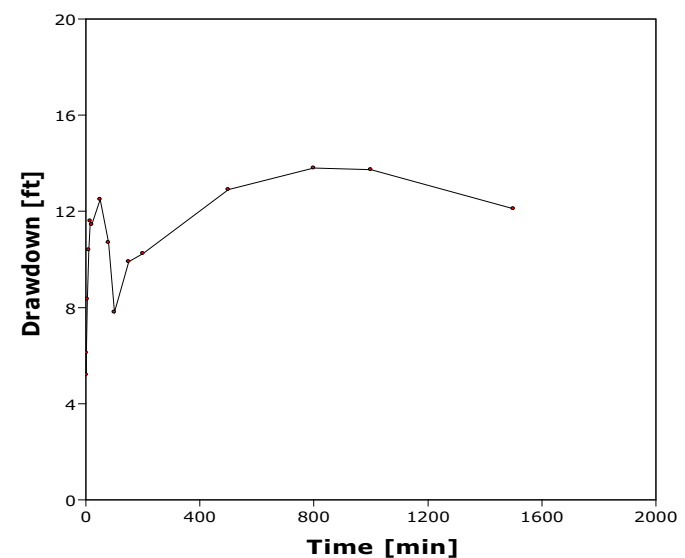

(vii) Ghuti

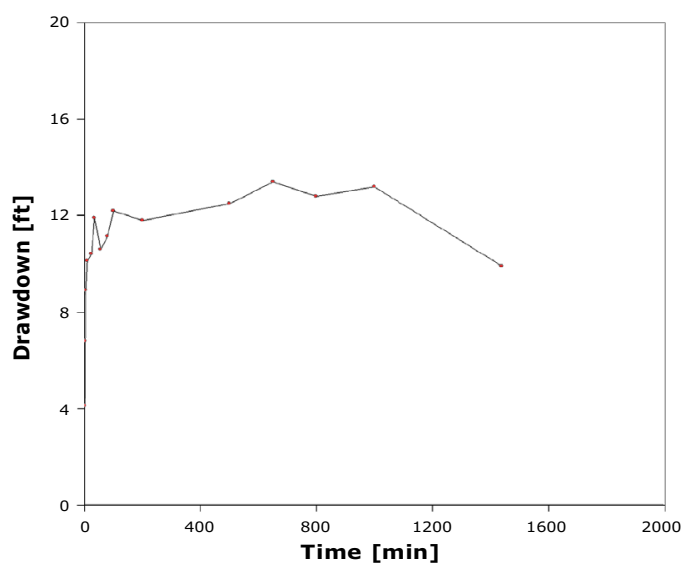

(viii) Hiwara Khurd

(b)

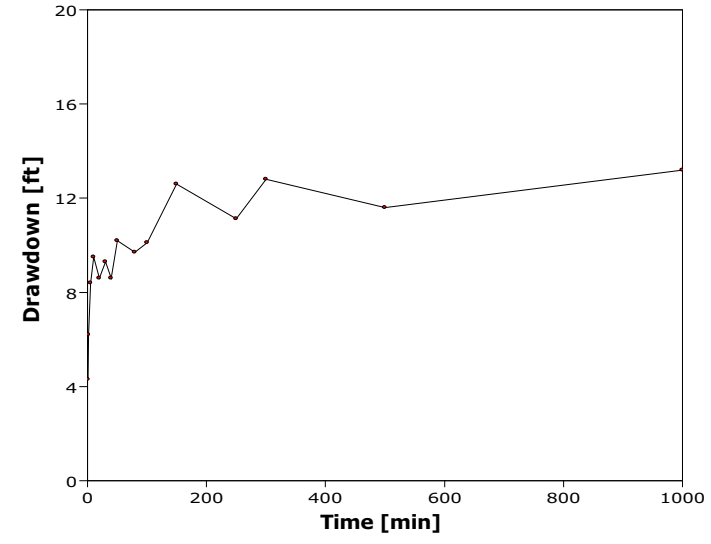

(ix) Isoli

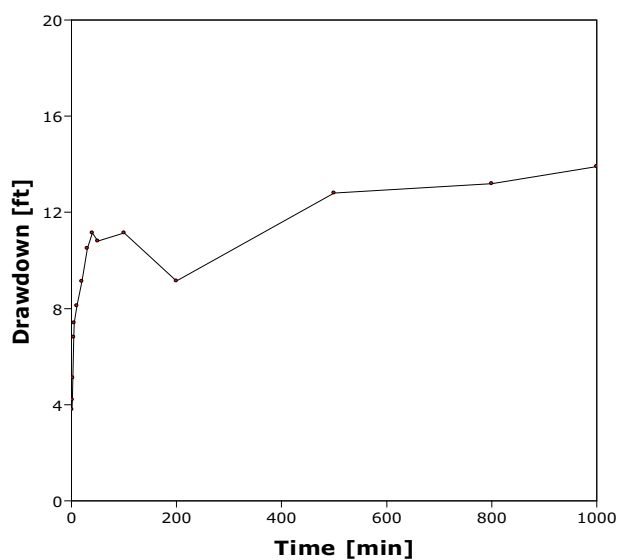

(x) Karkhed

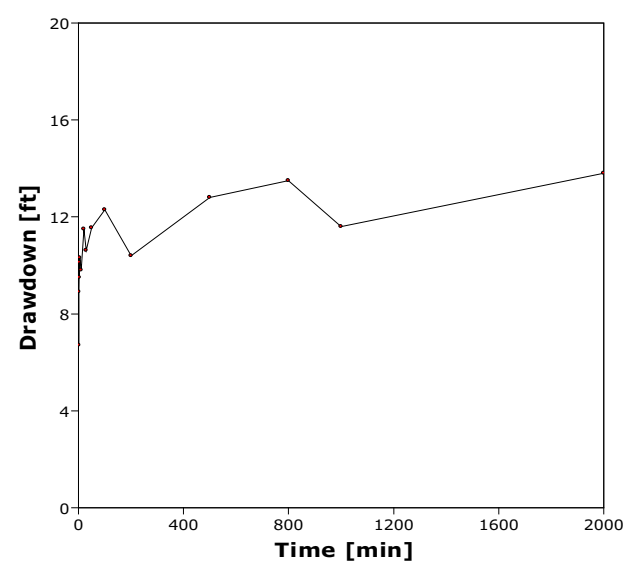

(xi) Mohadari

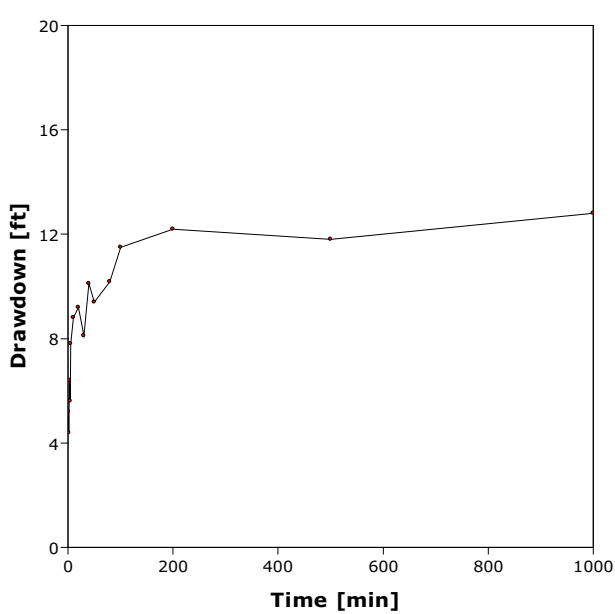

(xii) Mundephal

Fig. 5 continued 


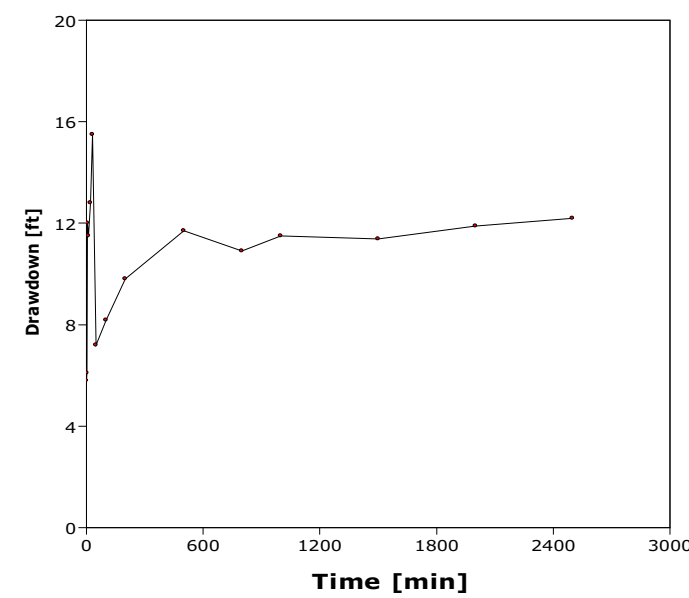

(xiii) Pardi

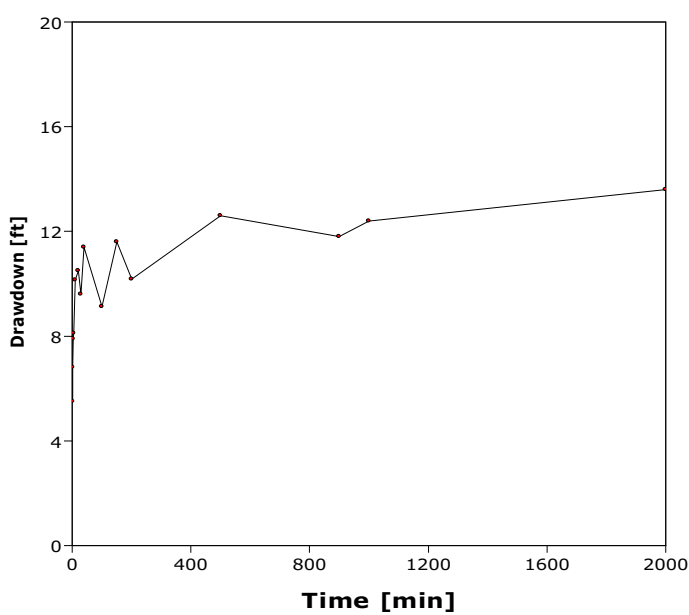

(xiv) Pimpal Khuta

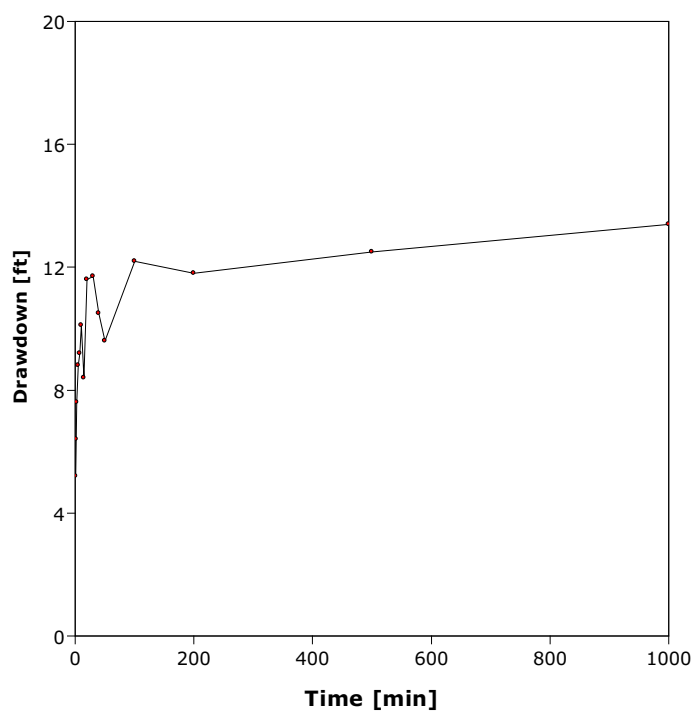

(xv) PimpariDhangar

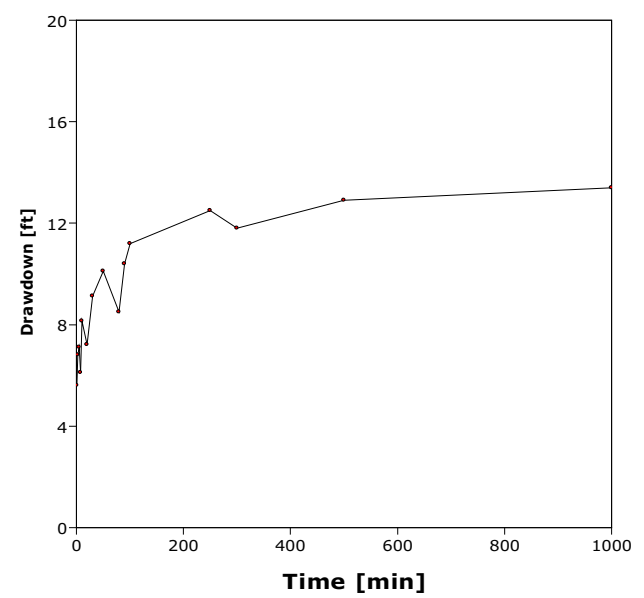

(xvi) Pimparkhed

(c)

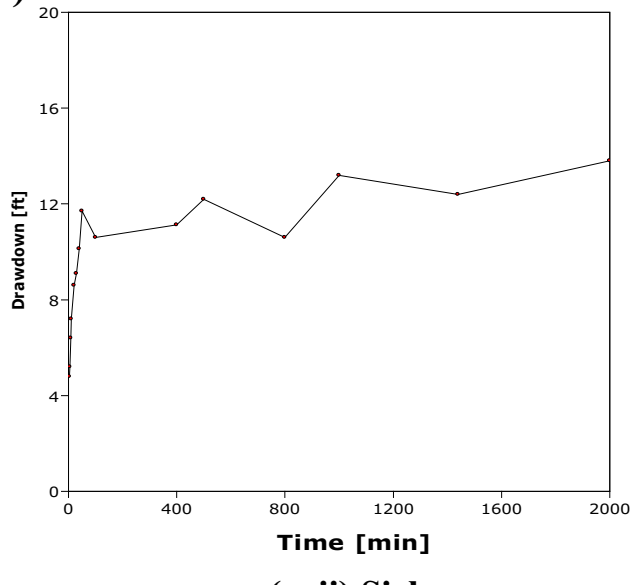

(xvii) Sirla

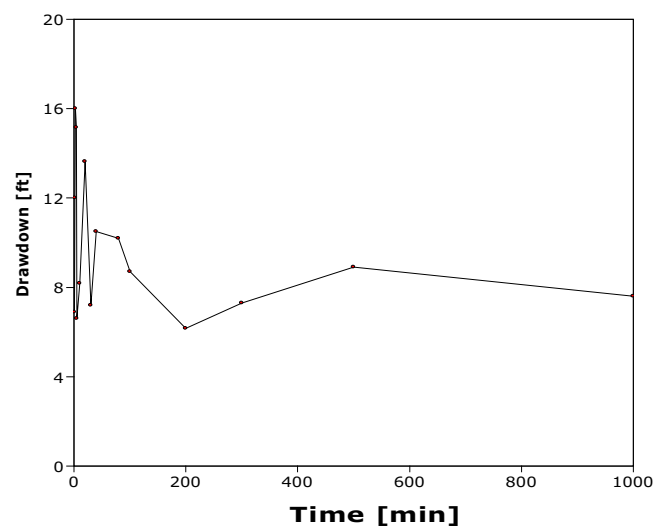

(xviii) Tarkhed

Fig. 5 continued 


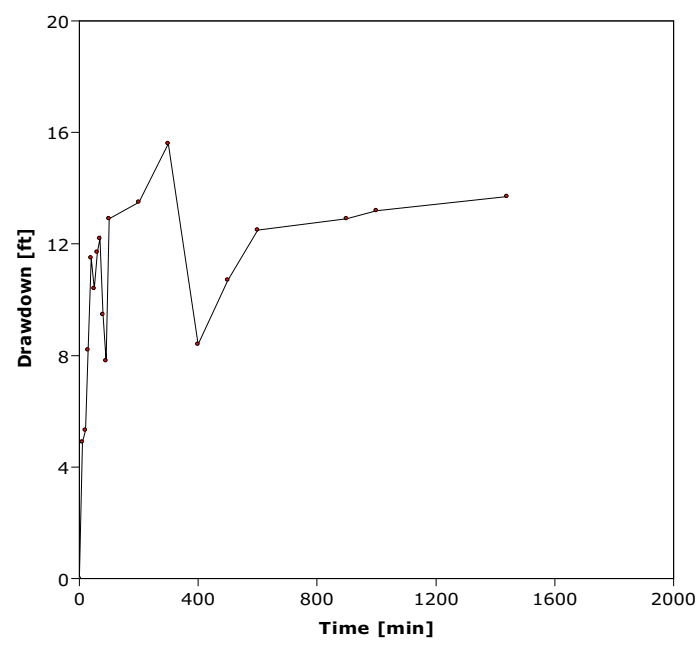

(xix)Uti

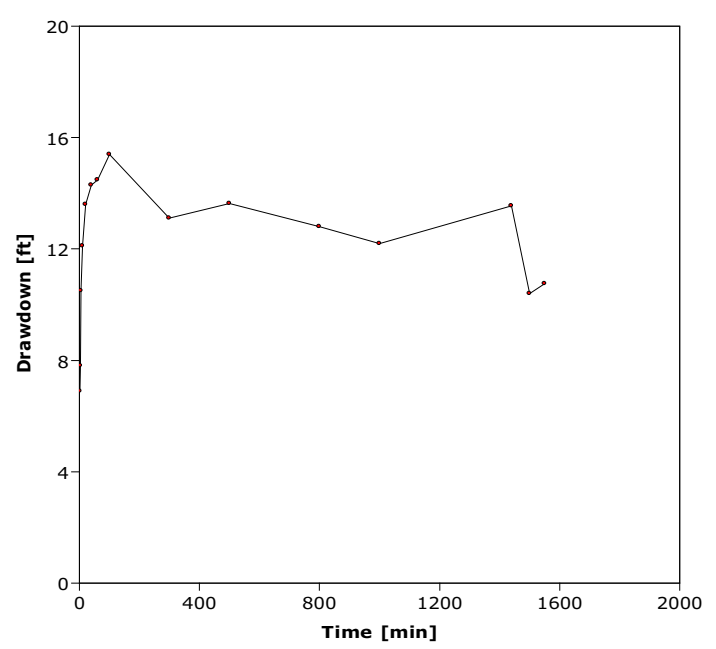

(xx) Wadali

\section{Conclusions}

The recent trend in increased abstraction from the Deccan Basalt aquifer to meet, in particular, the rising demand for irrigation is likely to continue. This has heightened concern in India that current groundwater abstraction from the shallow aquifer in certain areas may be exceeding that which is sustainable from limited groundwater resources and that water levels are declining as a result. The possible reduction in recharge due to climatic changes would exacerbate this problem. The cost implications of over abstraction and depletion of groundwater resources are potentially very serious, both in terms of wasted investment in agricultural development and in loss of cheap potable water supplies to many rural communities. Few studies have been undertaken on the shallow aquifer within the Deccan Basalts to understand the groundwater system, to quantify recharge or to assess the influence of pumped irrigation wells on the regional water table. There is a clear need for such research if sensible planning for sustainable development of groundwater and agriculture is to be made. Well storage effect is found to be significant during pumping tests in hard rock aquifers of low permeability.

The conventional interpretation technique gives rise to ambiguous results if well storage is ignored. In order to take into account the well storage effect, a radial flow model is suggested which yields a reliable estimation of aquifer parameters. For sustainability of water resources in Gurgaon district, extensive research plan was worked out. Recharge due to irrigation and rainfall has been estimated in accordance with CGWB methods. Irrigation recharge has been estimated using return flow factor method and rainfall recharge has been estimated using rainfall infiltration factor method as well as water table fluctuation 
Fig. 6 Thesis Log Log method using aquifer software 2014

Fig. 7 Thesis Semilog Method using aquifer software 2014
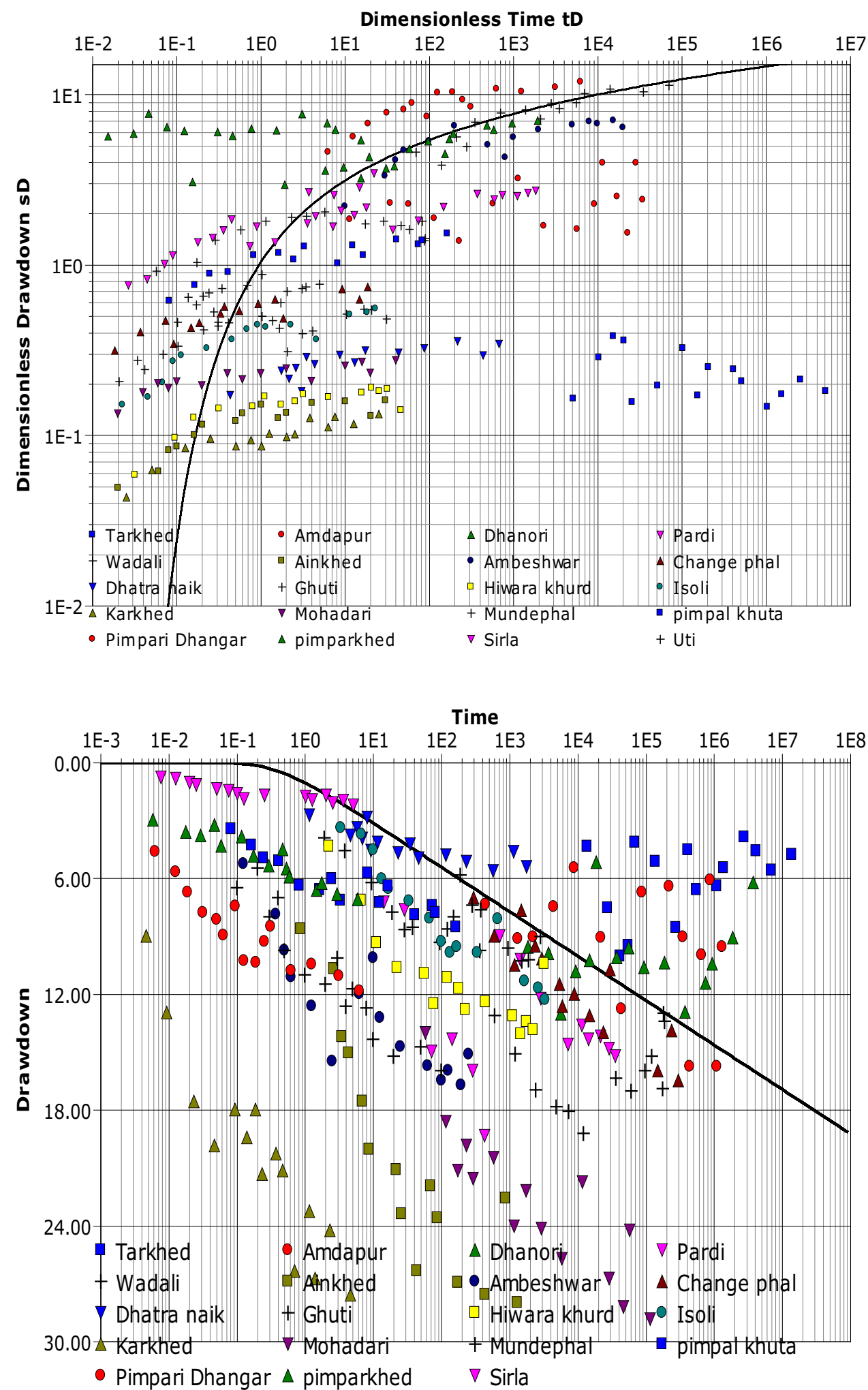

method. Recharge quantities has been normalized according to standard recommendations of respective methods. The Proposed simple procedure appears robust in dealing with the reproduction of the hydraulic head distribution in the Man River basin. Various automatic procedures or different manual calibration procedures would be expected 
Fig. 8 Recovery Template using aquifer software 2014

Fig. 9 Time Drawn Method using aquifer software 2014; Jacob's semi log (slope) method

\section{Equivalent Time}
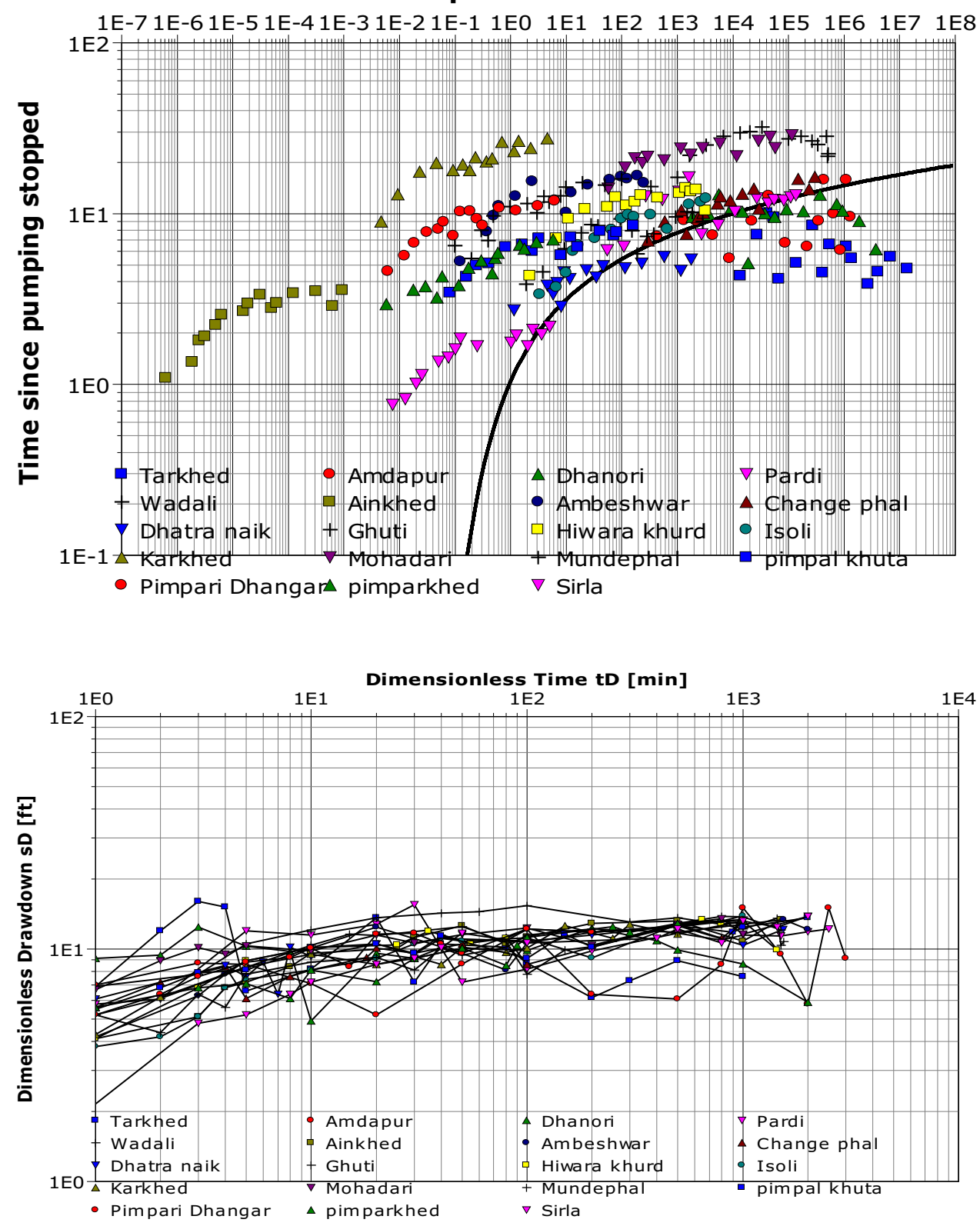
Fig. 10 Thesis with Jacob correlation using aqifer software 2014

Fig. 11 Jacob's semi log using aquifer software 2014
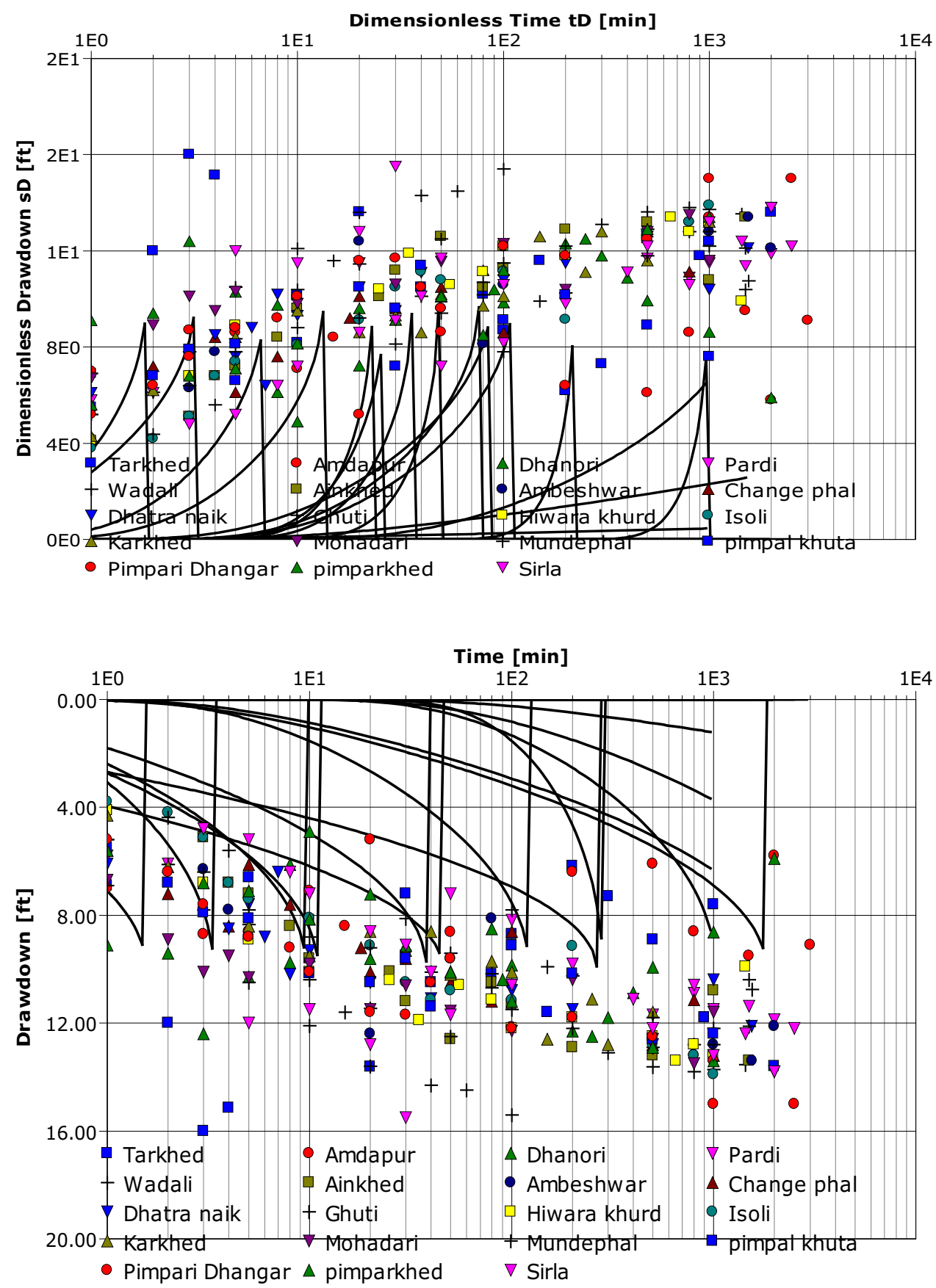

to derive a similar result. The proposed structured procedure is expected to be useful not only for the manual approach but also for automatic models. However, the manual approach based on our procedure allows modelers to easily incorporate geological study and experience at calibration process. Finally, we would like to emphasize the fact that any calibration procedure may not necessarily lead to exact boundary conditions, transmissivity distribution, and other parameters for a field aquifer due to our incomplete knowledge of the complexity of geology, simplification of models, errors in observations, etc.

\section{References}

Cooper HH, Jacob JF (1946) A generalized graphical method for evaluating formation constants and summarizing well field history. Trans Am Geophys Union 24(4):526-534

Detay M, Poyet P, Emsellem Y, Bernardi A, Aubrac G (1989) Development of the saprolite reservoir and its state of saturation: influence on the hydrodynamic characteristics of drillings in crystalline basement. C R Acad Sci Paris II 309:429-436

Hantush MS (1960) Modification of the theory of leaky aquifers. J Geophys Res 65:3713-3725

Hantush MS (1966) Analysis of data from pumping tests in anisotropic aquifers. J Geophys Res 71:421-426 
Hantush MS, Jacob CE (1955) Non-steady radial flow in an infinite leaky aquifer. Am Geophys Union Transcr 36:95-100

Javandel I, Witherspoon PA (1983) Analytical solution for partially penetrating in two-layer aquifer. Water Resour Res 19:567-578

Karanth KR (1987) Groundwater assessment, development and management. McGraw Hill Publishing Company Limited, New Delhi

Kruseman GP, de Ridder NA (1970) Analysis and evaluation of pumping test data, 2nd edn. International Livestock Research Institute Publications, Netherlands

Papadopulos IS, Cooper HH Jr (1967) Drawdown in a well of large diameter. Water Resour Res 3:241-244

Pathak BK (1984) Hydrogeological surveys and ground water resources evaluation in the hard rock areas of India. In: Proceedings of international workshop on rural hydrogeology and hydraulics in fissured basement zones, Roorkee, pp 14-15

Radhakrishna BP (1970) Problems confronting the occurrence of groundwater in hard rocks. In: Proceedings of seminar on groundwater potential in hard rocks of India, Bangalore, pp 27-44

Raj P (2001) Trend analysis of groundwater fluctuations in a typical groundwater year in weathered and fractured rock aquifers in parts of Andhra Pradesh. J Geol Soc India 58:5-13

Ruston KR (2003) Groundwater hydrology, conceptual and computational models. Wiley, London
Singh VS, Gupta CP (1986) Hydrogeological parameter estimation from pumping test on large diameter well. J Hydrol 87:223-232

Singh VS, Gupta CP (1991) Interaction computer programme to interpret pumping test data from large diameter wells. Water Resour J 169:33-41

Singhal BBS, Gupta RP (1999) Applied hydrology of fractured rocks. Kluwer, London

Sophocleous MA (1991) Combining the soil water balance and water level fluctuation methods to estimate natural groundwater recharge: practical aspects. J Hydrol 124:229-241

Taylor R, Howard K (2000) A tectono-geomorphic model of the hydrogeology of deeply weathered crystalline rock: evidence from Uganda. Hydrogeol J 8(3):279-294

Theim G (1906) Hydrologische Motheodem. Gebhardt, Leipzig

Theis CS (1935) The relation between the lowering of piezometric surface and the data and duration of discharge of a well using groundwater storage. In: American Geophysics Union Transcripts, 16th Ann Meeting, Part 2, pp 519-524

Vander Gun J, Lipponen A (2010) Reconciling groundwater storage depletion due to pumping with sustainability. Sustainability 2:3418-3435

Wyns R, Baltassat JM, Lachassagne P, Legchenko A, Vairon J, Mathieu F (2002) Application of magnetic resonance soundings to groundwater reserves mapping in weathered basement rocks (Brittany, France). Bull Soc Géol France, to be published 